Чечель Анна Олександрівна доктор економічних наук, доцент, завідувачка кафедри публічного управління та адміністрування, Донецький державний університет управління, вул. Карпінського, 58, м.Маріуполь, 87513, тел.: (062) 938-82-99, e-mail: annachechel.ac@ gmail.com, https://orcid.org/0000-0003-4307-5574

Мостовий Станіслав Едуардович лікар Комунального некомерційного підприємства «Онкологічний диспансер м.Маіруполя», магістрант АПП «Адміністративний менеджмент», Донецький державний університет управління, вул. Карпінського, 58, м.Маріуполь, 87513, тел.: (062) 938-82-99

\title{
МЕХАНІЗМИ ПУБЛІЧНОГО АДМІНІСТРУВАННЯ У ЗАБЕЗПЕЧЕННІ ІНФОРМАТИЗАЦІЇ СФЕРИ ОХОРОНИ ЗДОРОВ'Я: ЗАРУБІЖНІ ПРАКТИКИ
}

Анотація. Обгрунтовано необхідність забезпечення ефективного використання інформаційних ресурсів у всіх сферах діяльності, модернізації національних інформаційних ресурсів, формування необхідних умов для розвитку інформаційно-комунікаційної інфраструктури та технологій в умовах інтеграції інформаційної політики до світової спільноти та переходу держави на онлайнпослуги. Метою роботи $є$ визначення шляхів розвитку інформатизації галузі охорони здоров'я України на основі зарубіжних практик для ефективного впровадження механізмів публічного адміністрування цієї сфери. В статті визначено шляхи розвитку інформатизації галузі охорони здоров'я України на основі міжнародних практик для ефективного впровадження механізмів публічного адміністрування цієї сфери. Аналіз наукових розробок та впровадження інформаційних систем у сфері охорони здоров'я показав, що медичні системи розвиваються у світі прогресивно. На основі дослідження європейського досвіду електронної охорони здоров'я доведено, що кожна країна має власні стратегії розвитку електронної охорони здоров'я, різні пріоритети щодо інформаційного забезпечення, сфера електронної системи охорони здоров'я регулюється загальним законодавством. В умовах необхідності забезпечення захисту персональних даних, як критичного чинника подальшого розвитку електронної охорони здоров'я, важливими є питання удосконалення стандартів інформаційно-комунікаційних технологій, що забезпечуватимуть належну функціональну сумісність між системами i пристроями. Визначено 
інструментарій для розробки Національної стратегії розвитку електронної охорони здоров'я та оптимальні шляхи інформатизації галузі охорони здоров’я України з урахуванням досвіду розвинутих країн світу.

Ключові слова: публічне адміністрування, електронна система охорони здоров’я, інформатизація, інформаційна система, ідентифікація.

Chechel Anna Oleksandrivna Doctor of Economics, Associate Professor, Head of the Department of Public Administration and Administration, Donetsk State University of Management, Karpinskoho St., 58, Mariupol, 87513, tel .: (062) 938-8299, e-mail: annachechel.ac@gmail.com, https://orcid.org/0000-0003-4307-5574

Mostovyi Stanislav Eduardovych doctor of the Municipal Non-Commercial Enterprise "Oncology Dispensary of Mairupol", undergraduate of APP "Administrative Management", Donetsk State University of Management, Karpinskoho St., Mariupol, 87513, 58, tel.: (062) 938-82-99

\section{MECHANISMS OF PUBLIC ADMINISTRATION IN PROVIDING HEALTH INFORMATIZATION: FOREIGN PRACTICES}

Abstract. The necessity of ensuring effective use of information resources in all spheres of activity, modernization of national information resources, formation of necessary conditions for development of information and communication infrastructure and technologies in the conditions of integration of information policy into the world community and transition of the state to online services is substantiated. The aim of the work is to identify ways to develop informatization of the health care sector of Ukraine on the basis of foreign practices for the effective implementation of mechanisms of public administration in this area. The article identifies ways to develop the informatization of the health care sector of Ukraine on the basis of international practices for the effective implementation of mechanisms of public administration in this area. Based on a study of European eHealth experience, it has been proven that each country has its own strategies for the development of e-health, different priorities for information support, the field of e-health is regulated by general legislation. Given the need to ensure the protection of personal data as a critical factor in the further development of e-health, it is important to improve the standards of information and communication technologies that will ensure proper interoperability between systems and devices. The tools for the development of the National Strategy for the Development of Electronic Health Care and the best ways to informatize the health care sector of Ukraine, taking into account the experience of developed countries.

Keywords: public administration, electronic health care system, informatization, 
information system, identification

Постановка проблеми. Головним напрямком удосконалення сучасної інформаційної політики в умовах інтеграції до світової спільноти є перехід держави на онлайн-послуги, що дозволить наблизити послуги населенню, забезпечити демократичність інформаційного суспільства. Для реалізації цієї мети необхідно забезпечити ефективне використання інформаційних ресурсів у всіх сферах діяльності, модернізувати національні інформаційні ресурси, сформувати необхідні умови для розвитку інформаційно-комунікаційної інфраструктури та технологій.

Наявні дослідження щодо використання інформаційних технологій в галузі охорони здоров'я дозволяють забезпечити в межах обмеженого фінансування та існуючої медичної інфраструктури вирішення існуючих проблем медицини. В сучасних умовах можливим є дотримання єдиних вимог, які засновані на світових стандартах збереження, збору, обміну та обробки електронного варіанту медичної інформації, для більш глобального застосування використання локальних проектів з інформатизації медицини. Тому важливим і актуальним є дослідження зарубіжного досвіду розвитку механізмів публічного адміністрування у системі охорони здоров'я

Аналіз останніх досліджень і публікацій. Автори Бойко О. [1], Івануляк О. [2], Лялюк-Вітер Г. [2], Муляр Г. [3], Орлова Н. [4-5], Пашков В. [6], Рошак Й. [2], Семків Г. [2], Семчук Я. [2], Стеліга I. [2], Степанов В. [7], Чабан О. [1] дослідили сутність інформаційного забезпечення охорони здоров'я, світовий досвід впровадження в практику медичних інформаційних систем, але потребує подальшого дослідження питання удосконалення існуючих механізмів адміністрування сфери охорони здоров'я для забезпечення державної підтримки створення власних інформаційних систем та технологій.

Метою роботи $\epsilon$ визначення шляхів розвитку інформатизації галузі охорони здоров'я України на основі зарубіжних практик для ефективного впровадження механізмів публічного адміністрування цієї сфери.

Виклад основного матеріалу. Розвинені країни (США, Австралія, Японія, Свропа, Канада) впродовж тривалого часу мають комплексні програми інформатизації систем охорони здоров'я, які діють на території країни. Інтеграція усіх інформаційних систем (IC) окремих медичних закладів, регіональних, районних, міських (Regional Health Information Networks - RHINs, Regional Health Information Organizations - RHIOs, Regional Health Information Management Systems - RHIMSs в єдину IC системи охорони здоров'я країни (Національну інформаційну мережу охорони здоров'я - National Health Information Network (NHIN) або Національну інформаційну Інфраструктуру охорони здоров'я - 
National Health Information Infrastructure (NHII)) є головною метою таких програм. Такий підхід $\epsilon$ надзвичайно складним як з організаційного, так і технічного та фінансового аспектів, тому успішних прикладів таких медичних інформаційних систем (MIC) поки що не дуже багато у світі.

За останні 10 років галузь розробки та впровадження МIC у сфері охорони здоров'я в світі знайшла прогресивні механізми реалізації. Європейські організації й комісії по інформаційно-комунікаційним технологіям, які ставлять завдання об'єднати всі національні інформаційні мережі здоров'я країн Європейського союзу (ЄС), та забезпечити для населення цих країн дію уніфікованої електронної картки здоров'я (EHR) на всій території нинішнього СС впроваджують разом 3 національними програмами єдину програму Свропейського Союзу e-health, яка виконує такі першочергові задачі, як стандартизація, забезпечення страхового покриття незалежно від розташування, оброблення медичної інформації про пацієнта 3 використанням інформаційних технологій. Обсяг інвестицій $\mathrm{CC}$ в межах програми e-health без врахування відповідних національних програм вже склав сотні мільйонів євро [1].

Оскільки галузь охорони здоров'я має тенденцію до змін, а медичні дані $є$ найціннішим, що нагромаджуються та зберігаються в медичній установі, то МIC повинна бути побудована так, щоб ніякі зміни ії частин не приводили до втрати даних й не перешкоджали та не відображались на роботі медичних працівників у виконанні ними їх службових обов'язків. До відомих організацій із стандартизації та основних стандартів інформаційних технологій у сфері охорони здоров'я відносять: CCOW - Clinical Context Object Workgroup; CCR - Continuity of Care Record; CEN - Свропейський комітет з стандартизації; DICOM - Протокол обміну цифровими зображеннями та комунікації в медицині; EDIFACT - Обмін електронними даними для адміністрації, комерції та транспорту; HL7 - Стандарт обміну медичною інформацією, версія 2 та версія 3; HL7 CDA - HL7 Структура медичного документу; МКX-10 - Міжнародна класифікація хвороб; ICPC Міжнародна класифікація первинної допомоги; IEEE - Інститут електричної та електронної інженерії; IHE - Об'єднання підприємств охорони здоров'я; ISO OID - ISO Ідентифікатор Об'єкта; ISO/TK215 - Технічний комітет 215; LOINC - Назви та коди лабораторних тестів; NCSP - NOMESCO Класифікація хірургічних процедур; OpenEHR - Електрона медична карта; PKI - Інфраструктура відкритих ключів; SNOMED - Систематизована Номенклатура Медицини [1].

Світова спільнота крім розбудови національних інформаційних систем має досвід створення на міжнародному рівні інформаційних систем: Health Mapper (Медичний картограф), Global Atlas (Глобальний атлас), які з 1990-х років використовує Всесвітня організація охрони здоров'я (ВООЗ). Інформаційну систему Health Mapper, яка містить дані про освіту, медико-санітарну та 
демографічну інформацію, розташування дороги, громад, доступ до безпечної води, застосовують у понад 60 країнах в усіх регіонах ВОО3 для моніторингу низки інфекційних захворювань.

Без створення інтегрованих національних систем керування системою охорони здоров’я (CO3), без використання сучасних IKT неможливий подальший розвиток охорони здоров'я та медицини, про що свідчать національні програми розвитку охорони здоров'я більшості західних країн.

Стратегія розвитку електронної охорони здоров'я та основні напрями інформатизації медичної галузі визначені Резолюцією ВОО3 А58/21. Резолюція визначає, що електронна система охорони здоров'я має вплинути на системи охорони здоров'я шляхом поліпшення доступу до медико-санітарної допомоги, підвищення ефективності медичного обслуговування, для інвалідів і осіб літнього віку у віддалених районах. Електронна система охорони здоров'я має принести користь кінцевим споживачам, фахівцям, постачальникам медико-санітарних послуг за рахунок зміцнення здоров’я та підвищення якості обслуговування.

BOO3 тлумачить «електронну охорону здоров'я» (e-Health) як економічно надійну та ефективну форму використання інформаційно-комунікаційних технологій в інтересах охорони здоров'я та пов'язаних з нею галузей, у тому числі служби медичного нагляду, медико-санітарної допомоги, медичної освіти, медичної літератури, наукових досліджень та знань у галузі охорони здоров'я. E-Health дозволить вирішити важливі завдання в системі охорони здоров'я на регіональному та національному рівнях внаслідок соціально-культурних, епідеміологічних та демографічних змін [8].

Світовим лідером щодо запровадження електронної охорони здоров’я вважають Європу. Чимало дій зроблено 3 моменту прийняття Плану дій Свропейською Комісією для розвитку електронної охорони здоров'я в ЄС. При цьому кожна країна мала різні пріоритети: від формування окремого програмного забезпечення до розбудови інфраструктури національної електронної охорони здоров’я шляхом об’єднання існуючих регіональних та локальних мереж.

Стратегії розвитку електронної охорони здоров'я 3 визначеними планами заходів та цілями розроблені майже у всіх країнах-членах ЄС. Реалізація зазначених стратегій має позитивні результати. Аналіз питань захисту персональних даних та конфіденційності Європейської економічної спільноти дозволяє стверджувати, що сфера електронної системи охорони здоров’я у багатьох країнах регулюється загальним законодавством, зокрема законами про захист даних та про права пацієнтів. Лідерами з розробки нормативно-правової бази, яка адаптована до використання електронної охорони здоров'я, є Данія, Велика Британія, Норвегія, Естонія, Фінляндія, Словаччина, Шотландія, Швеція, Франція. Політика деяких інших країн відміняє певні правила, що стосуються 
даних про стан здоров'я [6].

Для європейських держав нормативно-правове забезпечення електронного документообігу вже не є нагальною проблемою. Більшість країн має можливість вибору, як зберігати записи про стан здоров'я (в паперовому або електронному варіанті). В Фінляндії обов'язковою $є$ електронна копія медичного запису. У Франції, Бельгії, Швейцарії, Іспанії, Італії необхідна згода пацієнта щодо електронного запису про його здоров'я. Використання електронного рецепту на законодавчому рівні переважно стосується згоди пацієнта, питань автентичності електронного підпису, підтвердження паперовою копією [9].

Головним чинником подальшого розвитку електронної охорони здоров'я $\epsilon$ забезпечення захисту персональних даних. Полеміка про межі законодавчого регулювання щодо накопичення інформації про пацієнта, її передачі суб'єктам для «вторинного» використання знаходиться у центрі уваги суспільства

Передбачають, що в найближче десятиліття трансформувати охорону здоров'я дозволять три напрямки розвитку інформаційних технологій: персоналізована медицина, мобільна охорона здоров'я (mHealth), інтерактивна охорона здоров'я (технології Web2.0).

3 метою забезпечення безпеки та конфіденційності, які визначені державними стандартами, головним питанням державної політики $\epsilon$ удосконалення стандартів інформаційно-комунікаційних технологій, які гарантують належну функціональну сумісність між пристроями та системами. Сдина взаємопов'язана архітектура $є$ елементом організаційної структури інформаційної системи в інформаційному просторі сфери охорони здоров'я. Серед ключових досягнень в даному напрямку $є$ : представлений початковий набір рекомендацій Єврокомісії, визначені основні елементи, які повинні бути створені 3 допомогою електронної охорони здоров'я, розроблено дорожню карту щодо забезпечення функціональної сумісності в області електронної охорони здоров’я в EC.

Окрім того, з метою надання транскордонних електронних послуг у СС працює електронний сервіс SPOCS (Simple Procedures Online for Cross-Border Services), що забезпечує здійснення простих онлайн процедур для транскордонних послуг, електронний портал E-CODEX (e-Justice Communication via Online Data Exchange), створений з метою забезпечення електронної взаємодії у сфері юстиції через онлайн-обмін даними, а також програма «еpSOS», що забезпечує доступ до транскордонних послуг у сфері охорони здоров'я, та електронний сервіс PEPPOL (Pan-European Public Procurement Online), запроваджений з метою онлайн доступу до публічних закупівель [2].

1 липня 2016 р. вступив у дію акт «Електронна ідентифікація, аутентифікація та довірчі послуги» (Electronic Identification and Authentication and Trust Services - 
eIDAS Regulation), який заклав нові стандарти для електронних транзакцій. За допомогою регламенту eIDAS передбачалося розширити повноваження та сферу діï попереднього нормативно-правового документа Директиви 1999/93/СС. До впровадження нового акту в більшості випадків громадяни, що мешкають в $\mathrm{CC}$, не могли використовувати електронну ідентифікацію в інших країнах-членах СС, оскільки національна система електронної ідентифікації їх країни не визнавалася в інших країнах. Основні терміни, які ввів регламент представлені в табл. 1.

Таблиця 1

Основні поняття, що вживаються в акті «Електронна ідентифікація, аутентифікація та довірчі послуги»

\begin{tabular}{|c|c|}
\hline Термін & Характеристика \\
\hline Підписувач & Особа, яка створює електронний підпис \\
\hline $\begin{array}{c}\text { Електронний } \\
\text { підпис }\end{array}$ & $\begin{array}{l}\text { Дані в електронній формі, які вкладені чи логічно пов’язані } з \\
\text { іншими даними електронної форми та які використовуються } \\
\text { підписувачем при підписанні }\end{array}$ \\
\hline $\begin{array}{l}\text { Покращений } \\
\text { електронний } \\
\text { підпис }\end{array}$ & $\begin{array}{l}\text { Дані, які безпосередньо пов’язані } 3 \text { підписувачем та } \\
\text { дозволяють ідентифікувати його, забезпечують контроль їх } \\
\text { використання єдиною особою та можливість відслідкувати } \\
\text { будь-яке втручання чи зміну даних; }\end{array}$ \\
\hline $\begin{array}{l}\text { Кваліфікований } \\
\text { електронний } \\
\text { підпис }\end{array}$ & $\begin{array}{l}\text { Покращений електронний підпис, який створено } \\
\text { кваліфікованим засобом і який базується на кваліфікованому } \\
\text { електронному сертифікаті. }\end{array}$ \\
\hline
\end{tabular}

Новий регламент застосовується в повній відповідності 3 принципами захисту персональних даних, передбаченими Директивою 95/46/СС «Про захист фізичних осіб при обробці персональних даних і про вільне переміщення таких даних», вимоги якої дійсні як для постачальників довірчих послуг, так i для органів нагляду. Зокрема, серед них: вимога обробляти персональні дані законно, чесно, у сумісний з цілями спосіб та зберігати їх у формі, що дозволяє встановлювати особу, на строк не довше, ніж це необхідно; зобов'язання для органу чи агентства, що визначає цілі і засоби обробки персональних даних, надавати особі, дані якої збираються, інформацію щодо цілей обробки та будьякої додаткової інформації, наприклад, стосовно одержувача іï даних, можливостей права доступу та права на виправлення тощо; право особи запитувати підтвердження щодо того, чи обробляються іiі дані, ким та 3 якою метою, й отримувати інформацію про логіку, яка використовується під час автоматизованої обробки даних.

У Данії розвинена система електронного обліку пацієнтів. У Франції 
електронна медична карта громадянина містить інформацію про страховку i хронічні хвороби. Історію звернень пацієнта і результати діагностики зберігає на своєму комп'ютері сімейний лікар. Охорона здоров'я в Швеції децентралізована, на федеральному рівні тільки приймаються закони, гроші розподіляються на регіональному та муніципальному рівнях. Швеція витрачає всього 2-3\% від бюджету, виділеного на охорону здоров'я, на розробку IT-рішень в медицині [5-6]. Структура національної інфраструктури електронних довірчих послуг Польщі представлена на рис. 1.

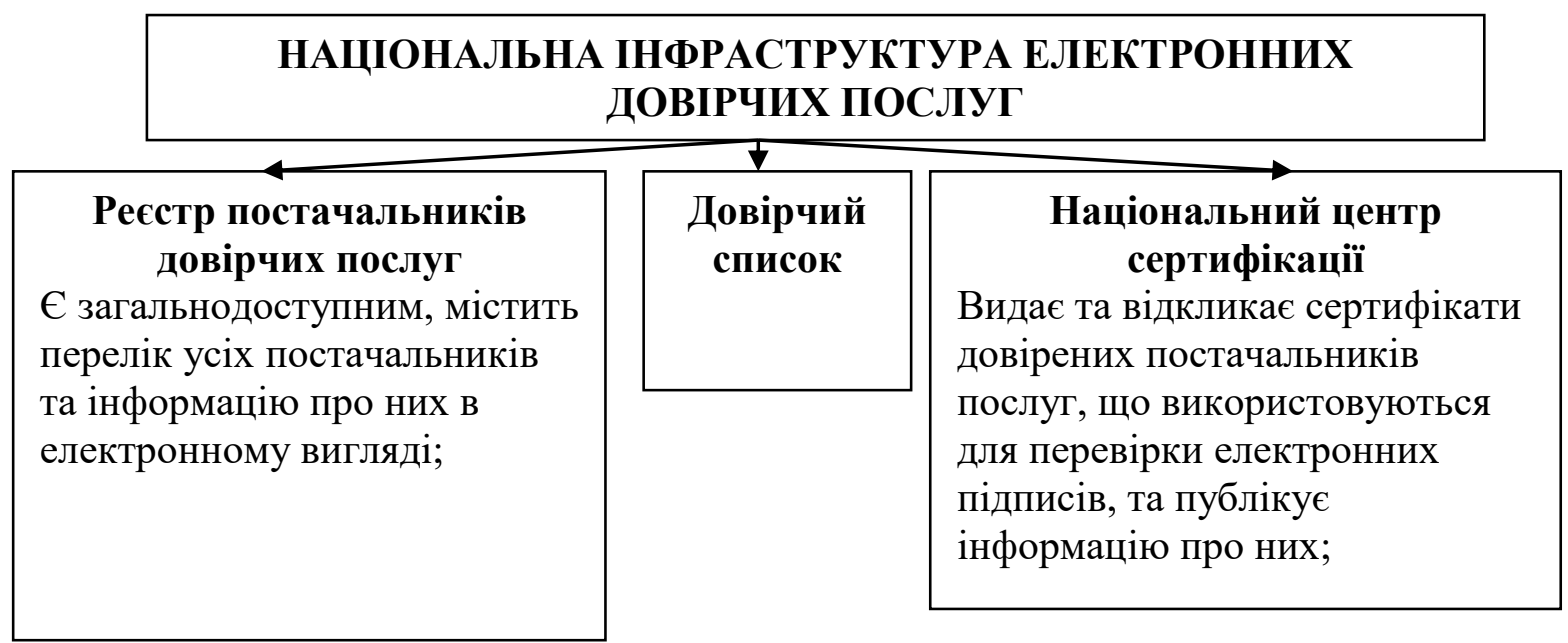

Pис.1. Структура національної інфраструктури електронних послуг Польщі (на основі [6])

Наявність укладеного договору страхування на весь період надання послуг щодо збитків, які можуть бути завдані споживачам, є обов'язковою вимогою закону до постачальників довірчих послуг. Дані та інформація щодо отримання та надання електронних послуг $\epsilon$ конфіденційними відповідно до діючого законодавства.

В Польщі, наприклад, діє небагато авторизованих центрів сертифікації, серед яких: CERTUM, Polska Wytwornia Papierow Wartosciowych, Krajowa Izba Rozliczeniowa Spółka Akcyjna та інші. Відповідальний державний нагляд, обмеження зловживань, детальне законодавче регулювання електронного документообігу дозволили використовувати електронний підпис у медичній, банківській, комерційній, судовій сферах.

Проблема інформаційного забезпечення управління галуззю охорони здоров’я потребує комплексного та системного підходу щодо іiі вирішення. ВОО3 розробила інструментарій для формування Національної стратегії розвитку електронної охорони здоров'я до 2020 р. (табл.2), визначений на основі досвіду розвинутих країн світу. 


\section{Інструментарій для розробки Національної стратегії розвитку}

\section{електронної охорони здоров'я}

\begin{tabular}{|c|c|}
\hline Напрям & Інструменти \\
\hline $\begin{array}{l}\text { Бачення національної } \\
\text { електронної } \quad \text { системи } \\
\text { охорони здоров’я }\end{array}$ & $\begin{array}{l}\text { Керувати процесом; взаємодіяти із зацікавленими } \\
\text { сторонами; створити стратегіний контекст; вивчити } \\
\text { тенденції і досвід; розробити проект бачення чому? } \\
\text { Що?як?; визначити необхідні компоненти; зібрати } \\
\text { інформацію прозовнішнє середовище/умови для } \\
\text { елеткронної охорони здоров'я; оцінити можливості } \\
\text { та прогалини; уточнити баченняі розробити } \\
\text { рекомендації }\end{array}$ \\
\hline $\begin{array}{l}\text { План дій національної } \\
\text { електронної системи } \\
\text { охорони здоров’я }\end{array}$ & $\begin{array}{l}\text { Керувати } \\
\text { процесом; } \\
\text { зацікавленими } \\
\text { дторонами; розробити напрямки } \\
\text { діяльності електронної охорони здоров’я; розробити } \\
\text { комплексний план дій; визначити макисмальні } \\
\text { потреби в ресурсах; скоригувати план } \\
\text { урахуванням фінансових обмежень; визначити етап } \\
\text { реалізації. }\end{array}$ \\
\hline $\begin{array}{l}\text { Моніторинг і оцінка } \\
\text { національної електронної } \\
\text { системи охорони } \\
\text { здоров'я }\end{array}$ & $\begin{array}{l}\text { Визначити показники для моніторингу оцінки; } \\
\text { визначити цільові заходи; визначити механізми } \\
\text { регулювання }\end{array}$ \\
\hline
\end{tabular}

Важливими компонентами формування національної електронної охорони здоров'я є: взаємодія із зацікавленими сторонами; керування процесом; вивчення досвіду інших країн та світових тенденції; створення стратегічного контексту; визначення необхідних компонентів; розробка проекту «чому? що? як?»; оцінка ризиків та можливостей; збір інформації про умови електронної охорони здоров’я та зовнішнє середовище; розробка рекомендацій.

План дій $з$ національної електронної охорони здоров'я має включати: взаємодію із зацікавленими сторонами; комплексний план дій та розробку напрямків діяльності електронної охорони здоров'я; визначення максимальної потреби в ресурсах; корегування плану з урахуванням фінансових обмежень; визначення етапи реалізації [5].

Висновки. Враховуючи зарубіжний та європейський досвід, можна визначити оптимальні шляхи інформатизації галузі охорони здоров'я України для реалізації реформ у цій сфері, а саме: впровадження електронного реєстру 
пацієнтів; оснащення робочих місць лікарів електронними системами підтримки прийняття клінічних рішень, засобами формування та ведення електронної історії хвороби, засобами електронної виписки лікарських засобів; розвиток інфраструктури інформаційних технологій у медицині, включаючи взаємодію лікувально-профілактичних закладів 3 регіональними i державними центрами оброблення даних; організація ефективного електронного обміну даними на всіх рівнях - усередині медичного закладу, між медичними установами, з одного боку, та контрольними органами - 3 іншого; інтеграція інформаційних систем лікувально-профілактичних закладів між собою, 3 іншими інформаційними продуктами та системами, а також з інформаційними мережами інших відомств i організацій; покращання інформаційної підтримки управлінської діяльності в лікувально-профілактичних закладах, включаючи контроль якості, формування статистики, передавання інформації та контроль рішень.

\section{Лimepamypa:}

1. Бойко О.,Чабан О., Огляд світової практики щодо впровадження медичних інформаційних систем та проблеми створення єдиного медико-інформаційного простору // Lviv Polytechnic National University Institutional Repository. http://ena.lp.edu.ua/bitstream/ntb/ 25505/1/50-365-370.pdf

2. Івануляк О. М., Стеліга І. І., Семчук Я. М. , Рошак Й. І., Семків Г. І., Лялюк-Вітер Г. Д., Сутність інформаційного забезпечення охорони праці в іфнтунг // Нафтогазова енергетика. 2011. № 2(15). C.106-109.

3. Муляр Г. Зарубіжний досвід функціонування системи охорони здоров'я в контексті забезпечення реалізації права на охорону здоров’я // Вісник АПСВТ. 2020. №1-2. С43-52.

4. Орлова Н. С. Механізми впровадження електронних довірчих послуг в систему охорони здоров'я // Збірник наукових праць Донецького державного університету управління. 2019. Том ХХ. Вип. 312. С. 6-14.

5. Орлова Н. С. Механізми державного управління у реформуванні системи охорони здоров’я // Публічне адміністрування та національна безпека. 2019. №6. https://doi.org/10.25313/2617-572X-2019-6-5377

6. Пашков В. М. Правове забезпечення реформування сфери охорони здоров'я // Український медичний часопис. 2017. №2(118). https://www.umj.com.ua/article/107586/pravovezabezpechennya-reformuvannya-sferi-ohoroni-zdorov-ya

7. Степанов В. Ю. Інформаційний простір охорони здоров’я України // Теорія та практика державного управління .2016. №3(54). С.1-5.

8. WHA.58.28 eHealth Resolution. http://www.who.int/healthacademy/media/WHA58-28en.pdf

9. Міжнародний досвід реформування системи охорони здоров'я (досвід країн Європейського Союзу): інформаційна довідка. Міністрество охорони здоров'я України. http://euinfocenter.rada.gov.ua/uploads/documents/29185.pdf

\section{References:}

1. Chaban, O., \& Bojko, O. (2013). Ohliad svitovoi praktyky schodo vprovadzhennia 
medychnykh informatsijnykh system ta problemy stvorennia iedynoho medyko-informatsijnoho prostoru [Review of world practice on the implementation of medical information systems and the problem of creating a single medical information space]. Retrieved from http://ena.lp.edu.ua/bitstream/ntb/25505/1/50-365-370.pdf [in Ukrainian].

2. Steliha, I. I., Semchuk, Ya. M., Roshak, J. I., Semkiv, H. I., Lialiuk-Viter, H. D., \& Ivanuliak, O. M. (2011). Sutnist' informatsijnoho zabezpechennia okhorony pratsi v ifntunh [The essence of information support for labor protection in ifntung]. Naftohazova enerhetyka - Oil and gas energy, 2(15), pp.106-109 [in Ukrainian].

3. Muliar, H. (2020). Zarubizhnyj dosvid funktsionuvannia systemy okhorony zdorov'ia v konteksti zabezpechennia realizatsii prava na okhoronu zdorov'ia [Foreign experience in the functioning of the health care system in the context of ensuring the implementation of the right to health care]. Visnyk APSVT - Visnyk APSVT, 1-2, pp.43-52 [in Ukrainian]..

4. Orlova, N. S. (2019). Mekhanizmy vprovadzhennia elektronnykh dovirchykh posluh v systemu okhorony zdorov'ia [Mechanisms for implementing electronic trust services in the health care system]. Zbirnyk naukovykh prats' Donets'koho derzhavnoho universytetu upravlinnia - Collection of scientific works of Donetsk State University of Management, 312, pp. 6-14 [in Ukrainian].

5. Orlova, N. S. (2019). Mekhanizmy derzhavnoho upravlinnia u reformuvanni systemy okhorony zdorov'ia [Public administration mechanisms in health care reform]. Publichne administruvannia ta natsional'na bezpeka - Public administration and national security, 6 . Retrieved from https://doi.org/10.25313/2617-572X-2019-6-5377 [in Ukrainian].

6. Pashkov, V. M. (2017). Pravove zabezpechennia reformuvannia sfery okhorony zdorov'ia [Legal support for health care reform]. Ukrains'kyj medychnyj chasopys - Ukrainian medical journal, 2(118). Retrieved from https://www.umj.com.ua/article/107586/pravove-zabezpechennyareformuvannya-sferi-ohoroni-zdorov-ya [in Ukrainian].

7. Stepanov, V. Yu. (2016). Informatsijnyj prostir okhorony zdorov'ia Ukrainy [Health care information space of Ukraine]. Teoriia ta praktyka derzhavnoho upravlinnia - Theory and practice of public administration, 3(54), pp.1-5 [in Ukrainian].

8. WHA.58.28 eHealth Resolution. who.int. Retrieved from http://www.who.int/healthacademy/ media/WHA58-28-en.pdf [in English].

9. Mizhnarodnyj dosvid reformuvannia systemy okhorony zdorov'ia (dosvid krain Yevropejs'koho Soiuzu): informatsijna dovidka [International experience in health care reform (experience of the European Union): information guide]. euinfocenter.rada.gov.ua. Retrieved from http://euinfocenter.rada.gov.ua/uploads/documents/29185.pdf [in Ukrainian]. 